\title{
Rózsás Eszter
}

DOI: 10.15170/DIKE.2020.04.02.01

habilitált egyetemi docens

PTE ÁJK

\section{In memoriam Ádám Antal (1930-2020)}

Nemini obesse, omnibus prodesse Senkinek sem ártani, és mindenkinek hasznára lenni

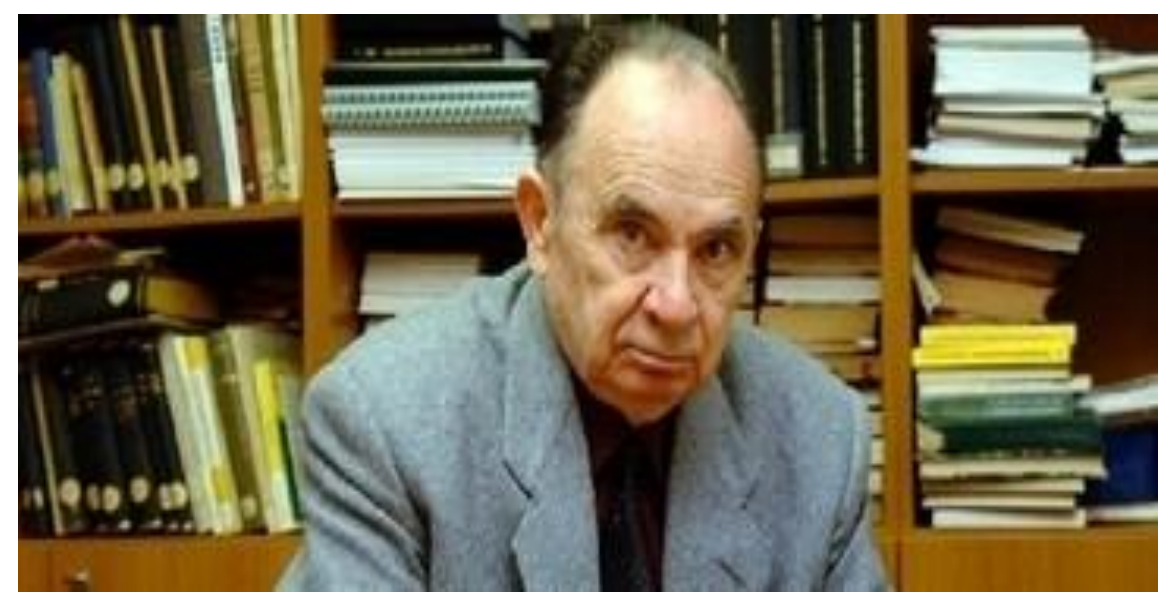

2020. május 7-én, életének 90. évében elhunyt Ádám Antal professzor úr. Halálával lezárult egy korszak a Pécsi Tudományegyetem Állam és Jogtudományi Karán, a legendás pécsi közjogi iskola utolsó tagja távozott közösségünkből.

Ádám Antal 1930. február 14-én született Jánoshalmán középbirtokos, földműves családból, Ádám Antal és Faddi Franciska harmadik gyermekeként. Elsőgenerációs értelmiségi habitusának megítéléséhez figyelmet érdemel, hogy anyai ágon az ugyancsak földmúves Faddi családból négy tekintélyes szerzetes tanárnő került ki a 20. század első felében, és anyai nagybátyja volt az országosan ismert ferences hitszónok, a 93. évében, 2002-ben elhunyt P. Faddi Othmár. Középiskolai tanulmányait Jánoshalmán kezdte, majd a nyíregyházi Kir. Kat. Gimnáziumban folytatta. 1945 szeptemberétől a Ciszterci Rend bajai III. Béla Gimnáziumának tanulója lett. Az egyházi iskolák 1948 júniusában bekövetkezett államosítása után, 1949-ben már az utód, állami gimnáziumban érettségizett.

1949 őszén felvételt nyert a Pécsi Tudományegyetem Állam- és Jogtudományi Karára. Tanulmányainak kitüntetéssel zárult befejezése után, 1953 júliusában a Pécsi Tudományegyetem Állam- és Jogtudományi Karának Alkotmányjogi Tanszékére nevezték ki tanársegédnek. 1954 szeptemberében Budapestre került, és a neves alkotmányjogász professzor, Beér János mellett tanult és dolgozott aspiránsként. Az államfői funkcióról írt kandidátusi értekezését 1958 júniusában védte meg. Ezt követően ismét a pécsi jogi karon dolgozott először egyetemi adjunktusi, 1960-tól egyetemi docensi, 1967-től pedig egyetemi tanári beosztásban. Különös tisztelet és barátság füzte első tanszékvezetőihez, Szamel Lajos professzorhoz és Bihari Ottó akadémikushoz. 1974-tôl 1975-ig dékánhelyettesi, 1975-től 1978-ig pedig dékáni tisztséget töltött be a Karon. 
Oktató munkájának keretében közremúködött a magyar alkotmányjog, az összehasonlító államjog, a közjogelmélet oktatásában. Magyar államjog címú kari jegyzete először 1972-ben, majd második bővített kiadásként 1983-ban jelent meg. Mindkét kiadás számos újranyomást ért el. 1990től 1998-ig a Magyar Köztársaság első Alkotmánybíróságának tagjaként tevékenykedett, ő volt a halálbüntetés eltörlésérôl szóló határozat (1990) előadó alkotmánybírája.

A rendszerváltozás számára is megújulást jelentett a tárgykörök és az elméleti kiinduló alapok tekintetében. A közjogi fogalmak, elvek és követelmények, valamint a belső és külső összefüggések feltárására irányuló, ún. dogmatikai módszer alkalmazásában tudatosan és megvallottan is Nagy Ernő dogmatikai szemléletét, stílusát és módszerét követte. A közjogi normák, viszonyok és intézmények világos, pontos leírásában és logikus rendszerezésében elragadtatással tisztelt első mestere, Csekey István igényességét tekintette követendő példának. A 20. század végén bontakozott ki Ádám professzornak a közjogelméletek történetének és jelenlegi irányzatainak oktatását célzó feltáró, gyűjtő, rendszerező és értékelő munkássága. Ennek alapján látott napvilágot 1999-ben a Bevez̨etés a közjogtanba címú jegyzete.

Az Alkotmányi értékeek és alkotmánybíráskodás címú akadémiai doktori értekezését 1999 áprilisában védte meg. 2000. március 1-jétől professor emeritusként, 2000-től 2014-ig a Jura címú folyóirat főszerkesztőjeként és a PhD Tanulmányok című kiadványsorozat szerkesztőjeként folytatta oktatói és tudományos munkáját. 2000 februárjától Állami egybárjog címmel hirdetett választható tantárgyat. Ennek tananyagát is tartalmazza a Bölcselet, vallás, állami egyhárjog címú, 2007-ben megjelent terjedelmes monográfiája, valamint a Bölcseletek, vallások, jogi alapértékeek címü, 2015-ben publikált könyve. Tudományos hitvallásnak is tekinthető megállapítása szerint: „A modern közjogtudománynak az ideológiai pluralitást és ezzel együtt az alkotmányos jogállam világnézeti semlegességet tiszteletben tartó attitüdje nem jelenthet értékmentességet, illetve értéksemlegességet. Folytonosan kutatnia és

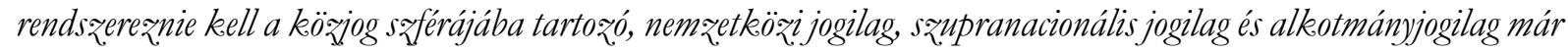
elismert vagy intézményesitésre és követésre érdemes értékeket. Ezáltal ösz̨tönöznie kell arra, hogy a polgárok nyitottá váljanak az egyén és a közösség javát szolgáló, éltetö kultúrák termékenyitö hatásai és hasznositható értékei iránt. A vallások és vallástanok, az etikák, a természetjogi felfogások, az értéktanok, továbbá más jelentös eszmeáramlatok és tudományágak eredményeire is tekintettel fel kell dolgoznia és be kell mutatnia az alkotmányjogilag elismert, illetve védelemre és hasznositásra érdemes, az embert, a közösségeket, a társadalmat, az. emberiséget, a természeti környezetet, az élóvilágot oltalmazó, a fenntartható fejlödést elómoz ditó közjogi értékeeket, fel kell tárnia és meg kell jelölnie a korszerütlen, a veszélyes, a hátrányos, a csalárd, tehát az értéktelen megnyilvánulásokat".

A 2017/18-as tanév ôszi szemeszteréig tanított Pécsett. A joghallgatók három alkalommal, a 2000-2001-es, a 2001-2002-es valamint a 2003-2004-es tanévben a jogi fakultás legnépszerúbb oktatójává választották.

70. születésnapján, 2000 februárjában három külföldi és huszonöt magyar alkotmányjogász tanulmányát tartalmazó kötettel köszöntötte ôt a pécsi jogi kar. Az Adamante Notare címú, 2005ben megjelent ünnepi kötetben tíz külföldi és húsz hazai kollega tisztelgett előtte tanulmányával. A 2010-ben kiadott emlékkötetben pedig tekintélyes magyar közjogászoktól származó huszonnégy tanulmány olvasható. 


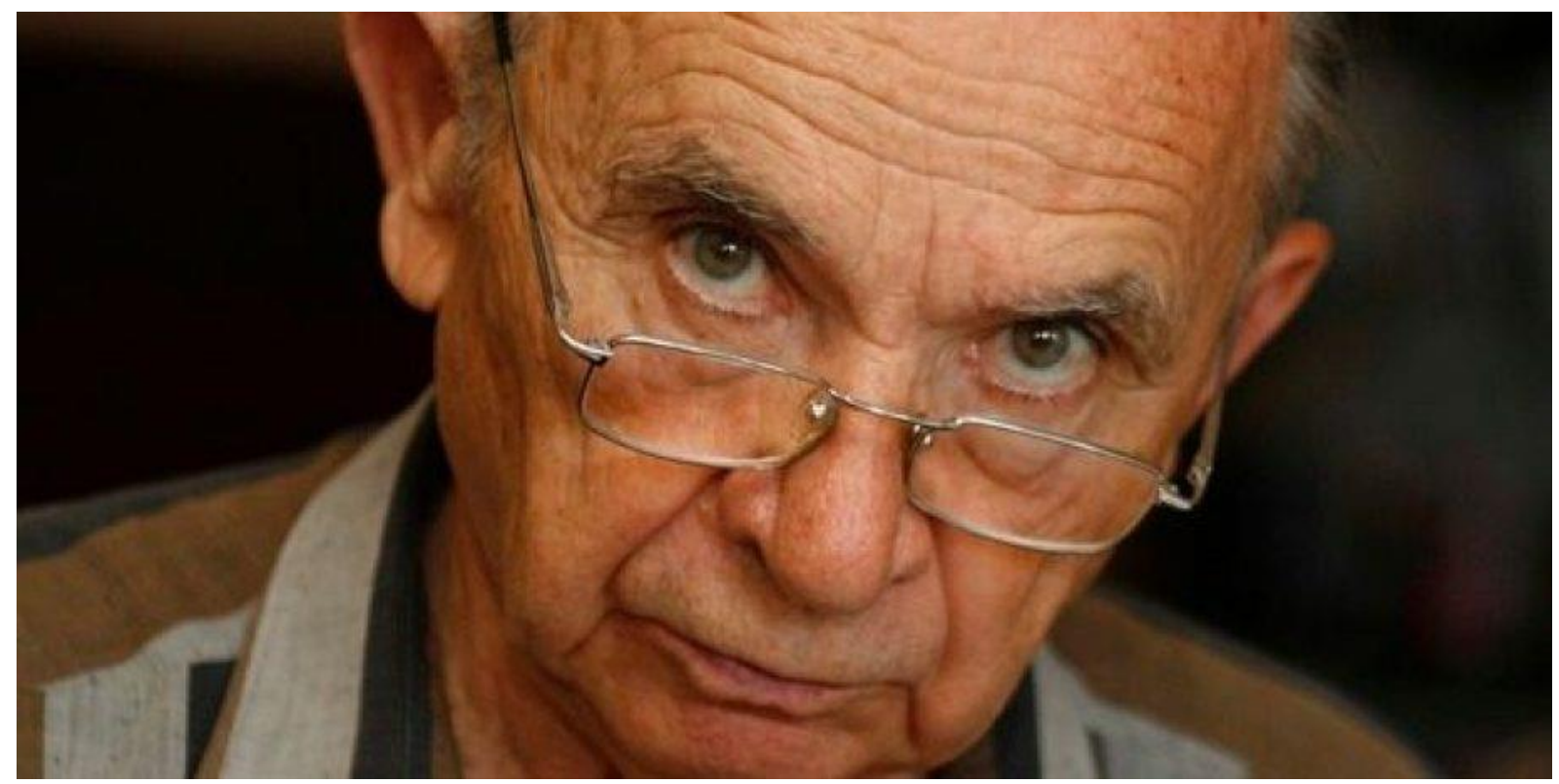

Félezer szakmai publikáció, több mint 100 külföldön tartott előadás, mintegy 150 újságcikk, többszáz alkotmánybírósági határozatban való közremúködés és 70 általa szerkesztett kötet jelzi a nagyívű szakmai életpályát. Emellett gyakran szerepelt az MTA doktori értekezések hivatalos bírálójaként, rendszeresen véleményezett habilitációs pályázatokat, részt vett a Bolyai ösztöndíjasok munkáinak minősítésében. Doktorandusz hallgatói közül számosan szereztek PhD fokozatot. Beszélt németül, franciául, angolul és oroszul.

Tudományos kutatómunkájának eredményét több alkalommal állami, egyetemi kitüntetéssel ismerték el. (A teljesség igénye nélkül: Magyar Köztársasági Érdemrend középkeeresðtje a csillaggal - 1990, Magyar Felsöoktatásért miniszteri kitüntetés - 2000, Pro Facultate Iuridico-Politica Universitatis Quinqueeclesiensis érdemérem arany fokozata, PTE ÁJK - 2005, Sžnt-Györgyi Albert-díj, Igazságügyi Minisztérium - 2009, Honoris causa doctor et professor cím, PTE 2013, Tüke-díj, Pécs Megyei Jogú Város - 2016.)

Ádám Antal személyiségét közvetlenség, szerénység, önzetlen segítőkészség, derū és fáradhatatlan aktivitás jellemezte. A pécsi jogi karon eltöltött hét évtizede alatt szenvedélyes, szuggesztív előadásain diákok ezrei ismerhették meg óriási szakmai tudását. Joghallgató nemzedékek tanulták meg tôle az emberség, a méltányosság és a jogászi hivatás tiszteletének fontosságát. A tudományos fokozat megszerzése előtt álló doktorandusz hallgatók tudományterülettől függetlenül - kivétel nélkül számíthattak professzor úr szakmai-emberi segítségére.

Professzor úr vallotta, hogy a „bona fides és az aequitas római jog által kimunkált alapkövetelményét részletező alapelvek alaptörvényi rögzitése a közzélet és magánélet bármely területére adaptálva új távlatát nyitná meg az. emberi megnyilvánulások kulturáltságának és nemesedésének. Mindazonáltal a jóbiszemüség, a tisztesség és a méltányosság alaptörvényi elöírásának biánya természetesen nem lehet akadálya a kölcsönös tisztelet, az. elözékenység, az udvariasság, a segitökészség, a jottékonyság, az apró figyelmesség, valamint a körültekintō méltányosság minél szélesebb körü érvényesitésének". Mindezen tulajdonságok jellemezték őt emberi kapcsolataiban. 
Mindent elmondanak azok a jellemzők, amelyekkel kollégái, egykori tanítványai illeték: bölcsessége hatalmas tapasztalaton nyugszik; tudományos érdeklődése olthatatlan; kollegiális segítőkészsége közismert; fantasztikus memóriával rendelkező szenvedélyes tanár; kiválóan kérdező, érdeklődő, a másik álláspontját messzemenően tiszteltben tartó vitapartner; a mindennapok szülte konfliktusok feloldásában a méltányos megoldások és az észszerű, megnyugtató kompromisszumok híve, aki minden körülmények közt elvetette az indulatos vagy sértő megnyilvánulásokat; eszköztelenül, szerényen szuggesztív és szeretnivalóan kedves; valódi humanista. E sorok íróját Ádám professzor úr végtelen türelme és segítő szándéka, az élet minden területére vonatkozó tanácsai (ahogy ő mondaná: „korszerű” életvezetési javaslatai) segítették azokban a nehéz helyzetekben, amikor úgy érezte, hogy - a mások által félreértelmezett oktatói szabadság következtében - csorba esett személyes igazságán. Ádám professzor bölcsessége, szakmai igényessége, az oktatás-kutatás iránti alázata, a kollégák felé irányuló őszinte érdeklődése és segítókészsége, a hallgatókkal való mindenkor méltányos bánásmódja példaként szolgál az egyetemi oktatók, tudósok, elméleti és gyakorlati szakemberek számára!

Kedves Professzor Úr! Rendhagyó módon - de mindannyiunk okulására - a Te soraiddal búcsúzom Tőled. Az általad legjelentősebbnek és követendőnek tartott bölcseleti felismerés Arisztotelész azon koncepcióján alapul, ,mely szerint az ember alapvető tulajdonsága (eidosza) a boldogságra törekevés. A boldogság elérésének öt feltétele pedig: az okosság (phronésis₹), a helyes gondolkodás (ortosz logosz), a megfelelö lelkialkat, a szabad akarat (poairészisz) és a folytonos változáshoz igazodó optimális (meszotész). A beképzelt, önbitt túlzásnak (bübrisz) pedig végzetszerü szankciója a kudarc, vagy a kegyetlen sors (moira)”.

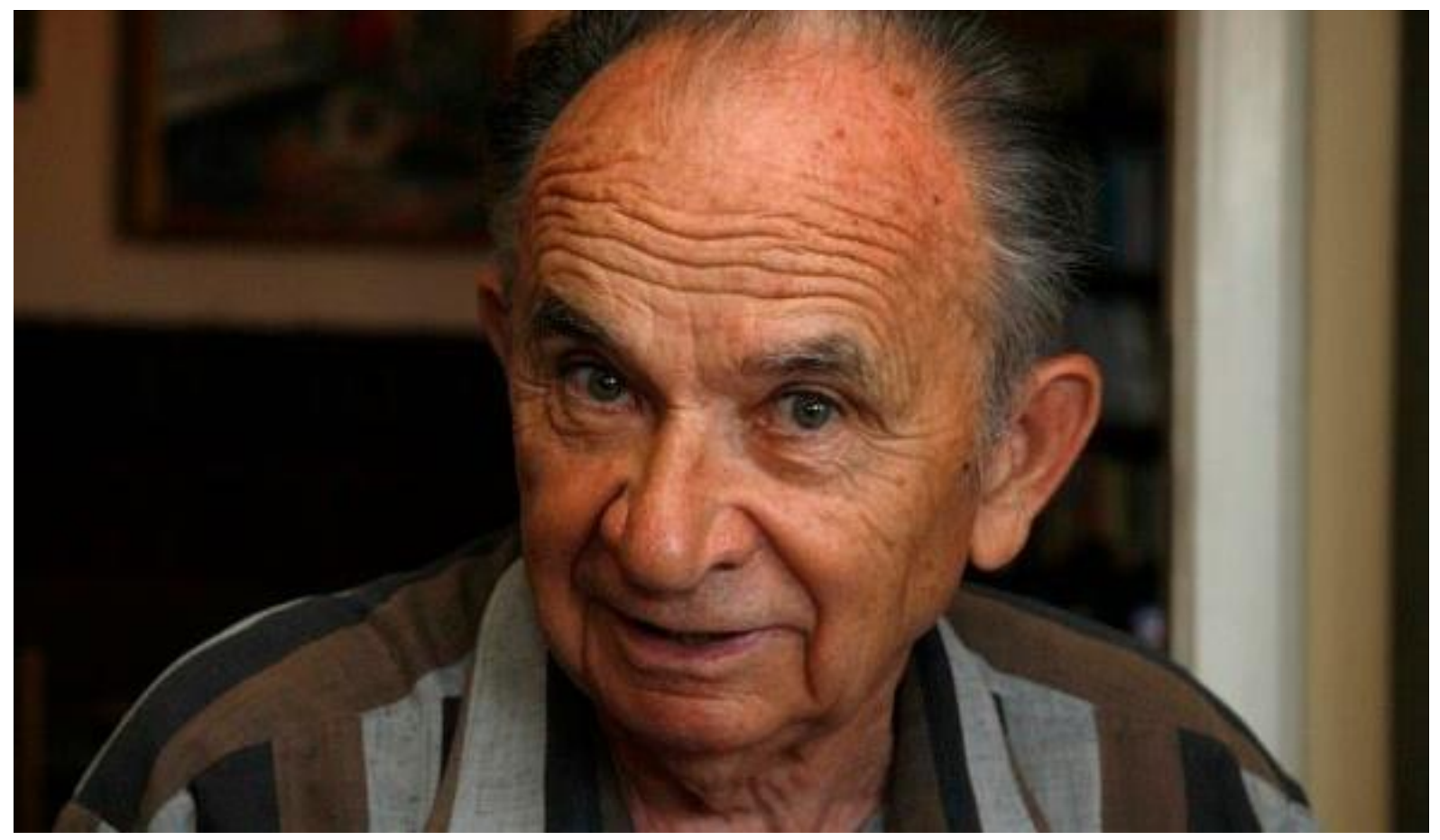

Nyugodj békében, Professzor Úr! Pécs, 2020. november 1. Mindenszentek 